\title{
METODE PARTISIPATIF PADA PELATIHAN FINANCIAL LIFE SKILLS UNTUK MENINGKATKAN LITERASI KEUANGAN PENGAJAR TRIDAYA GROUP BANDUNG
}

\author{
Hadita Akmala ${ }^{(1)}$, Ramayani Yusuf ${ }^{(2)}$, dan Eki Dudi Darmawan ${ }^{\left({ }^{3)}\right.}$ \\ ${ }^{1}$ Ilmu Administrasi Negara, Fakultas Ilmu Sosial dan Ilmu Politik, Universitas Garut \\ ${ }^{2,3}$ Administrasi Keuangan, Fakultas Ekonomi Bisnis, Politeknik Piksi Ganesha Bandung \\ ${ }^{1}$ Jalan Raya Samarang 52A Hampor Garut 44151 \\ 2,3 Jalan Gatot Soebroto 301 Bandung 40274 \\ E-mail : akmala@uniga.ac.id ${ }^{1)}$ yusuframayani@gmail.com ${ }^{2}$ ekidudidarmawan@gmail.com ${ }^{3)}$
}

\begin{abstract}
ABSTRAK
Pelatihan Financial Life Skills merupakan serangkaian pelatihan yang mengombinasikan pelatihan soft skill dan literasi keuangan untuk dapat membuat keputusan keuangan yang tepat bagi semua orang. Pelatihan ini menggunakan metode partisipatif dalam penyampaian materinya. Tujuan penulisan ini adalah untuk memberikan gambaran pelatihan Financial Life Skills untuk meningkatkan literasi keuangan pada pengajar Tridaya Group Bandung. Penulisan ini menggunakan metode kualitatif merupakan penelitian yang digunakan untuk menyelidiki, menemukan, menggambarkan, dan menjelaskan kualitas atau keistimewaan dari pengaruh sosial yang tidak dapat dijelaskan, diukur atau digambarkan melalui pendekatan kuantitatif. Peserta pelatihan merupakan karyawan Tridaya Group Bandung yang telah memiliki masa kerja 2- 15 tahun, dipilih secara acak oleh bagian HRD. Profesi peserta terdiri dari pengajar, office boy dan sekretaris wilayah. Hasil penelitian menunjukkan metode partisipatif yang digunakan dalam pelatihan dapat meningkatkan pemahaman peserta pelatihan Metode Partisipatif memberikan pemaknaan yang berbeda kepada peserta dan memberikan kesempatan pada peserta menemukan sendiri tujuan dan goal setting yang diharapkan pada setiap modul pelatihan. Pelatihan menggunakan metode partisipatif mampu memberikan peningkatan pemahaman dari peserta, terbukti dengan meningkatnya nilai dari pretest dan post-test yang diadakan sebelum dan sesudah pelatihan dilaksanakan. Berdasarkan hasil kuesioner yang disebar oleh Trainer, kepuasan peserta pelatihan Financial Life Skills pengajar Tridaya Group adalah sebesar 92,5\%
\end{abstract}

Kata Kunci: Financial Life Skills, Literasi Keuangan, Metode Partisipatif, Tridaya Group, Soft skills

\section{PENDAhuluan}

Dalam struktur organisasi sekolah, pengajar merupakan salah satu ujung tombak dalam proses pembelajaran. Ukuran keberhasilan suatu pembelajaran adalah dengan tingkat pemahaman siswa terhadap materi yang diberikan oleh pengajar pada proses pemberian materi. Untuk dapat memberikan materi yang paripurna, pengajar perlu mempersiapkan diri baik secara jasmani maupun rohaninya agar penyampaian berjalan baik

Sebuah lembaga pendidikan memerlukan manusia sebagai sumber daya pendukung utama untuk mencapai tujuan yang telah ditetapkan. Sumber daya manusia yang berkualitas akan turut memajukan lembaga (Wahyu Rahmat Maulana, 2016)

Banyak faktor yang mempengaruhi kondisi pengajar pada saat mengajar, faktor tersebut adalah faktor internal pengajar, terdiri dari kondisi fisik pengajar dan kondisi psikis pengajar. Faktor yang kedua adalah faktor eksternal, yang terdiri dari lingkungan (fisik, sosial, kultural)dan instrumen (metode mengajar, alat pelajaran, waktu pembelajaran) (Taufik dkk., 2014)

Faktor psikis pengajar merupakan salah satu faktor yang mesti diperhatikan. Tidak sedikit pengajar yang memiliki masalah psikis mengakibatkan cara mengajar dan memperlakukan siswa menjadi tidak baik. Tidak di pungkiri masalah kesejahteraan pengajar sangat mendukung psikis pengajar untuk dapat memberikan pengajaran dengan baik. Kinerja guru yang tinggi akan menghasilkan peserta didik (SDM) yang cerdas/berilmu dan berkualitas serta berkepribadian baik, hal ini selaras dengan misi pendidikan yang menjadi tanggung jawab profesional setiap guru. Juga sesuai dengan apa yang diamanatkan oleh Undang-undang No. 20 Tahun 2003 (Sisdiknas, Pasal 3), "Pendidikan nasional berfungsi mengembangkan kemampuan dan membentuk watak serta peradaban bangsa yang bermartabat dalam rangka mencerdaskan kehidupan bangsa, bertujuan untuk berkembangnya potensi peserta didik agar menjadi manusia yang beriman dan bertakwa kepada Tuhan Yang Maha Esa, berakhlak mulia, sehat, berilmu, cakap, kreatif, mandiri, dan menjadi warga negara yang demokratis serta bertanggung jawab".

Pengajar merupakan salah satu profesi yang telah diatur dalam undang-undang, permasalahan yang dihadapi guru cukup beragam, salah satunya mengenai kesejahteraan. Pengajar tetap swasta misalnya, 
mendapatkan gaji tidak pasti karena mengikuti kondisi keuangan sekolah. Permasalahan tersebut membutuhkan solusi salah satunya yakni dengan pengelolaan keuangan. Namun, belum ada data mengenai perilaku pengelolaan keuangan guru. Padahal, pengajar dengan pengelolaan yang baik dapat memanfaatkan secara optimal sumber dana sehingga (Zulbetti dkk, 2019)tujuan keuangan.

Hutang individu dan pengeluaran rumah tangga (Ludlum dkk., 2019) adalah salah satu yang membuat pengajar tidak dapat memberikan pelayanan terbaik bagi peserta didik. YEP USAID sejak tahun 2017 mengembangkan suatu pelatihan (Lopus,dkk., 2019) dengan tujuan untuk membuka wawasan dan memberikan pemecahan masalah keuangan. Pelatihan yang bernama Financial Life Skills merupakan sebuah aktivitas yang terstruktur untuk mengintegrasikan kurikulum bahan ajar finansial dengan keterampilan hidup, dengan tujuan dapat meningkatkan kualitas hidup peserta menjadi lebih bermakna(Lopus dkk., 2019)

Manajemen keuangan pribadi yang sukses tidak hanya membutuhkan pemahaman tentang konsep keuangan tertentu, tetapi juga mengetahui cara menganggarkan dan menyadari rasio antara aset, tabungan, dan hutang seseorang(Shaanika, 2018). Financial Life Skills ditujukan bagi semua yang terlibat dalam pengelolaan kemampuan keuangan untuk merencanakannya, membantu untuk memahami kebutuhan sehingga meningkatkan kemampuan dalam pengelolaan keuangan. Penelitian terdahulu mengenai Financial Life Skills, Financial Life Skills of Finnish College Students: A Pilot Study on Credit Cards and Budgets (Ludlum dkk., 2019), menunjukkan temuan mahasiswa di Finlandia mengalami kesulitan dalam mengelola keuangannya, sehingga mereka sangat tergantung pada kartu kredit. Hal ini menunjukkan adanya hubungan bahwa literasi keuangan yang rendah berpengaruh pada keputusan keuangan. Untuk menghindari hal tersebut, Tridaya Group berusaha membuat karyawannya lebih produktif dalam bekerja dan memberikan layanan terbaik bagi peserta didiknya.

Dalam upayanya menciptakan pelatihan yang dapat mudah diaplikasikan oleh peserta, YEP USAID mengembangkan metode pelatihan partisipatif. Kegiatan pembelajaran partisipatif menurut Sudjana dalam (Elian \& Ilyas, 2020) terdiri atas kegiatan membelajarkan dan kegiatan belajar dimana terjadi keikutsertaan warga belajar dalam kegiatan merencanakan, melaksanakan, dan menilai kegiatan pembelajaran. Dalam hubungan ini tutor berupaya memotivasi dan melibatkan warga belajar dalam ketiga kegiatan tersebut yaitu perencanaan, pelaksanaan, dan penilaian kegiatan pembelajaran(Sharma dkk, 2021). Sesuai dengan namanya, dalam pembelajaran partisipatif memberi ruang dan waktu yang lebih luas bagi peserta untuk menerima dan memproses materi ajar yang diterimanya(Taufik,dkk., 2014). Diharapkan dengan metode partisipatif, peserta dapat menerima materi yang disampaikan dan dapat meningkatkan kemampuannya dalam mengelola keuangan.

\section{RUANG LINGKUP}

Penelitian ini menitikberatkan kepada peningkatan keterampilan hidup berbasis literasi keuangan untuk pengajar di Tridaya Group melalui metode partisipatif. Penelitian ini membatasi pada pemahaman tentang literasi keuangan dan kemampuan keterampilan hidup dengan modul yang diberikan, hal lain diluar kedua batasan tersebut dapat dijadikan bahan kajian peneliti lain.

\section{BAHAN DAN METODE}

Literasi Finansial menurut Regulasi OJK Nomor 76/POJK.07/2016 adalah sekumpulan pengetahuan, keterampilan, dan keyakinan, yang mempengaruhi sikap dan perilaku untuk meningkatkan kualitas pengambilan keputusan dalam manajemen keuangan untuk mencapai kesejahteraan. Literasi keuangan didefinisikan sebagai proses/rangkaian atau aktivitas dalam meningkatkan knowledge (pengetahuan), skill (keterampilan), confident (keyakinan) masyarakat luas dan konsumen sehingga mampu mengelola dengan baik keuangan pribadinya(Zulbetti \& Ratna, 2018). Untuk memahami financial life skills, terdapat 14 modul yang akan disampaikan kepada peserta. Modul tersebut dapat dilihat pada tabel 1 . 
Tabel 1. Jabaran Modul Pelatihan Financial Life Skills

\begin{tabular}{|c|c|c|}
\hline & & \\
\hline $\begin{array}{l}\text { No } \\
1\end{array}$ & $\begin{array}{l}\text { Pengantar Soft } \\
\text { Skills dan } \\
\text { Financial Skills }\end{array}$ & $\begin{array}{l}\text { Ringkasan Modul } \\
\text { Sesi perkenalan dan saling } \\
\text { mengenal, dibuat aturan dasar } \\
\text { untuk pembentukan } \\
\text { lingkungan pelatihan yang } \\
\text { kondusif }\end{array}$ \\
\hline 2 & $\begin{array}{l}\text { Membangun } \\
\text { Rasa Percaya } \\
\text { Diri } \\
\end{array}$ & $\begin{array}{l}\text { Sesi membangun kepercayaan } \\
\text { dirinya }\end{array}$ \\
\hline 3 & $\begin{array}{l}\text { Membangun } \\
\text { Sumber Daya } \\
\text { Insani }\end{array}$ & $\begin{array}{l}\text { Sesi mengetahui kelebihan, } \\
\text { kelemahan, ancaman dan } \\
\text { peluang dari dirinya dengan } \\
\text { menggunakan metode SWOT }\end{array}$ \\
\hline 4 & $\begin{array}{l}\text { Menjadi Orang } \\
\text { yang } \\
\text { Bertanggung } \\
\text { Jawab: Pribadi } \\
\text { dan Keuangan } \\
\end{array}$ & $\begin{array}{l}\text { Sesi memaksimalkan peserta } \\
\text { untuk mengetahui perbuatan } \\
\text { yang bertanggungjawab dan } \\
\text { mana yang tidak } \\
\text { bertanggungjawab }\end{array}$ \\
\hline 5 & $\begin{array}{l}\text { Berpikir Kritis } \\
\text { dalam Membuat } \\
\text { Keputusan }\end{array}$ & $\begin{array}{l}\text { Sesi belajar berpikir kritis dan } \\
\text { menganalisa cara berpikir } \\
\text { kritis menggunakan metode } \\
\text { PACED }\end{array}$ \\
\hline 6 & $\begin{array}{l}\text { Menentukan } \\
\text { Tujuan Hidup: } \\
\text { Pribadi dan } \\
\text { keuangan }\end{array}$ & $\begin{array}{l}\text { Sesi mengetahui tujuan } \\
\text { hidupnya secara pribadi } \\
\text { maupun keuangan }\end{array}$ \\
\hline 7 & $\begin{array}{l}\text { Membuat } \\
\text { Anggaran dan } \\
\text { Mengelola } \\
\text { Keuangan }\end{array}$ & $\begin{array}{l}\text { Sesi membuat anggaran } \\
\text { dengan melihat Opportunity } \\
\text { Cost dan mendahulukan } \\
\text { kebutuhan daripada keinginan }\end{array}$ \\
\hline 8 & $\begin{array}{l}\text { Mengatasi } \\
\text { Kebiasaan } \\
\text { Menunda } \\
\text { Pekerjaan }\end{array}$ & $\begin{array}{l}\text { Sesi menyelesaikan tugas- } \\
\text { tugas yang penting dan } \\
\text { membuat prioritas pekerjaan. }\end{array}$ \\
\hline 9 & $\begin{array}{l}\text { Merencanakan } \\
\text { Tabungan }\end{array}$ & $\begin{array}{l}\text { Sesi merencanakan menabung } \\
\text { merupakan suatu pilihan } \\
\text { untuk melakukan pengeluaran } \\
\text { atau menabungkan uangnya }\end{array}$ \\
\hline 10 & $\begin{array}{l}\text { Kredit dan } \\
\text { Pinjaman }\end{array}$ & $\begin{array}{l}\text { Sesi membahas dua aspek } \\
\text { terkait bagaimana menjadi } \\
\text { peminjam (debitur) yang } \\
\text { cerdas }\end{array}$ \\
\hline 11 & $\begin{array}{l}\text { Komunikasi } \\
\text { Positif }\end{array}$ & $\begin{array}{l}\text { Sesi bagaimana dapat } \\
\text { berkomunikasi secara asertif } \\
\text { dan mempengaruhi orang } \\
\text { lain. }\end{array}$ \\
\hline 12 & $\begin{array}{l}\text { Skema } \\
\text { Pembiayaan dan } \\
\text { Investasi Ilegal }\end{array}$ & $\begin{array}{l}\text { Sesi mengetahui skema } \\
\text { pembiayaan dan investasi } \\
\text { illegal untuk dihindari. }\end{array}$ \\
\hline 13 & $\begin{array}{l}\text { Kerja tim dan } \\
\text { Profesional }\end{array}$ & $\begin{array}{l}\text { Sesi bagaimana bekerja dalam } \\
\text { tim dan bagaimana bersikap } \\
\text { professional }\end{array}$ \\
\hline 14 & $\begin{array}{l}\text { Membuat } \\
\text { Rencana Aksi }\end{array}$ & $\begin{array}{l}\text { Sesi membuat rencana aksi } \\
\text { untuk tujuan keuangan } \\
\text { maupun tujuan pribadinya. }\end{array}$ \\
\hline
\end{tabular}

Sumber : Rencana Pembelajaran Financial Life Skills (Diolah olah peneliti) (USAID, 2018)

Untuk pengawasan dan monitoring pelatihan Financial Life Skills sendiri menggunakan alat-alat yang dapat memberikan gambaran secara utuh informasi yang diperlukan sesuai dengan kebutuhan pelatihan(Zulbetti dkk, 2019), alat- alat monitoring dapat dilihat pada tabel 2 .

Tabel 2.Alat-Alat Monitoring dan Evaluasi Pelatihan Financial Life Skills

\begin{tabular}{|c|c|c|}
\hline $\begin{array}{c}\text { No } \\
\text { Form }\end{array}$ & Isi form & $\begin{array}{c}\text { Waktu } \\
\text { pengisian }\end{array}$ \\
\hline 1B & Data peserta & $\begin{array}{c}\text { Sebelum } \\
\text { pelatihan }\end{array}$ \\
\hline 2B & $\begin{array}{c}\text { Pre-test yang berhubungan } \\
\text { dengan pengetahuan mengenai } \\
\text { literasi keuangan dan persepsi } \\
\text { diri mengenai soft skill }\end{array}$ & $\begin{array}{c}\text { Sebelum } \\
\text { pelatihan }\end{array}$ \\
\hline 3B & $\begin{array}{c}\text { Post-test yang berhubungan } \\
\text { dengan pengetahuan mengenai } \\
\text { literasi keuangan dan persepsi } \\
\text { diri mengenai soft skill }\end{array}$ & $\begin{array}{c}\text { Setelah } \\
\text { pelatihan }\end{array}$ \\
\hline 4B & $\begin{array}{c}\text { Kepuasan peserta terhadap } \\
\text { trainer /pelatih }\end{array}$ & $\begin{array}{c}\text { Setelah } \\
\text { pelatihan }\end{array}$ \\
\hline 5B & $\begin{array}{c}\text { Kepuasan peserta terhadap } \\
\text { pelatihan }\end{array}$ & $\begin{array}{c}\text { Setelah } \\
\text { pelatihan }\end{array}$ \\
\hline
\end{tabular}

Sumber: Rencana Pembelajaran Financial Life Skills, YEP USAID, 2018 (USAID, 2018)

Pembelajaran participative adalah kegiatan pembelajaran di mana semua pihak, termasuk pendidik dan peserta didik, terlibat secara aktif dalam setiap kegiatan pembelajaran. Keikutsertaan peserta didik itu diwujudkan dalam tiga tahapan kegiatan pembelajaran yaitu tahap perencanaan program (program planning), pelaksanaan (program implementation), dan penilaian (program evaluation) kegiatan pembelajaran.(Komalasari, 2013). Prinsip dasar pembelajaran participative terdiri dari:

1. Berpusat pada Peserta (Learner Centered)

2. Berangkat Dari Pengalaman Belajar (Experiential Learning)

3. Berorientasi Pada Tujuan (Goals Oriented)

4. Menekankan Kerja Sama

Ciri-ciri Pembelajaran Partisipatif memiliki hal sebagai berikut:

1. Pendidik menempatkan diri pada kedudukan yang tidak serba mengetahui semua bahan belajar.

2. Pendidik memainkan peran untuk membantu peserta didik dalam melakukan kegiatan pembelajaran.

3. Pendidik melakukan motivasi terhadap peserta didik supaya berpartisipasi dalam menyusun tujuan belajar, bahan belajar, dan langkah-langkah yang akan ditempuh dalam kegiatan pembelajaran.

4. Pendidik bersama peserta didik melakukan kegiatan saling belajar dengan cara bertukar pikiran mengenai isi, proses dan hasil kegiatan pembelajaran, serta tentang cara-cara dan langkah-langkah pengembangan pengalaman belajar untuk masa berikutnya.

5. Pendidik berperan untuk membantu peserta didik dalam menciptakan situasi yang kondusif untuk 
belajar, mengembangkan semangat belajar bersama, dan saling tukar pikiran.

6. Pendidik mengembangkan kegiatan pembelajaran berkelompok, memperhatikan minat perorangan, dan membantu peserta didik untuk mengoptimalkan respons terhadap stimulus yang dihadapi dalam kegiatan pembelajaran.

7. Pendidik mendorong peserta didik untuk meningkatkan semangat berprestasi.

8. Pendidikan mendorong dan membantu peserta didik untuk mengembangkan kemampuan pemecahan masalah yang diangkat dari kehidupan peserta didik.

Pelaksanaan Pelatihan Financial Life Skills dilakukan selama 2 hari yaitu dari tanggal 16 sampai dengan 17 September 2018. Bertempat di Gedung Sakola Tridaya, jalan Encep Kartawirya, jam 08.00 - 17.00 WIB yang terdiri 14 modul. Setiap langkah pembelajaran pada Financial Life Skills ini mencoba untuk menarik partisipasi peserta dengan menggunakan games, diskusi baik secara kelompok kecil maupun kelompok besar, dan role-play. Empat belas modul yang diberikan secara garis besar dibagi menjadi dua kelompok, dapat dilihat pada tabel 3 .

Tabel 3. Sebaran Modul Secara Garis Besar

\begin{tabular}{|c|c|}
\hline Literasi Keuangan & Keterampilan Hidup \\
\hline 1. Menentukan tujuan & 1. Membangun rasa percaya \\
\hline keuangan & 2. Membangun sumber daya \\
\hline $\begin{array}{l}\text { dan mengelola } \\
\text { keuangan } \\
\text { 3. } \text { Merencanakan }\end{array}$ & $\begin{array}{l}\text { 3. Menjadi orang yang } \\
\text { bertanggungjawab : Pribadi } \\
\text { dan Keuangan }\end{array}$ \\
\hline $\begin{array}{l}\text { tabungan } \\
\text { 4. Kredit dan pinjaman }\end{array}$ & $\begin{array}{l}\text { 4. Berpikir kritis dalam } \\
\text { mengambil keputusan }\end{array}$ \\
\hline $\begin{array}{l}\text { 5. Skema pembiayaan } \\
\text { dan investasi illegal }\end{array}$ & $\begin{array}{l}\text { 5. Mengatasi kebiasaan } \\
\text { menunda pekerjaan } \\
\text { 6. Komunikasi positif } \\
\text { 7. Kerja tim dan professional } \\
\text { 8. Membuat rencana aksi }\end{array}$ \\
\hline
\end{tabular}

Sumber: Rencana Pembelajaran Financial Life Skills, YEP USAID, 2018 (diolah penulis)

Peserta pelatihan adalah 17 orang karyawan Tridaya Group dengan masa kerja yang tidak ditetapkan dipilih secara acak dengan sebaran yang dapat dilihat pada tabel 4.
Tabel 4.Profil Peserta

\begin{tabular}{|l|c|}
\hline \multicolumn{1}{|c|}{ Profil } & Jumlah \\
\hline Jumlah peserta & 17 \\
Jumlah peserta laki- laki & 6 \\
Jumlah peserta perempuan & 11 \\
& \\
Rentang usia : & \\
23-29 & 5 \\
30-34 & 5 \\
35-39 & 3 \\
40-47 & 4 \\
\hline Pendidikan : & 1 \\
SMP & 1 \\
SMA & 14 \\
S1 & 1 \\
S2 & \\
\hline
\end{tabular}

Sumber : diolah penulis 2018

Untuk memperoleh data keberhasilan metode partisipatif yang digunakan dalam pelatihan, menggunakan data nilai pre-test dan data nilai post, kemudian dibandingkan dan dilihat apakah ada kenaikan atau penurunan.

\section{PEMBAHASAN}

Pada pelaksanaan kegiatan pelatihan Financial life skills ini merupakan upaya dalam meningkatkan kemampuan karyawan dalam mengelola keuangannya sehingga tidak terjadi salah pengelolaan keuangan yang dapat memberikan efek pada kinerja karyawan Tridaya Group.

\subsection{Pelaksanaan Pelatihan}

Pelaksanaan pelatihan Financial Life Skills terdiri dari 14 modul, setiap modul pembelajaran terdiri dari :

1. Menarik minat

Merupakan tahap pengkondisian peserta sehingga peserta diarahkan untuk fokus pada pembelajaran yang akan diberikan.

2. Pembelajaran Utama

Pembelajaran utama terdiri dari beberapa tahapan dan beberapa metode pembelajaran partisipatif.

3. Penutup

Menarik kesimpulan dari semua materi yang diberikan di pembelajaran utama.

Pembelajaran partisipatif yang dilakukan selama pelatihan ini berprinsip pada:

1. Berpusat pada peserta

Untuk memegang prinsip ini, setiap pembelajaran Financial Life Skills ini tidak diberikan modul yang berisi teori, tetapi peserta diberi kesempatan untuk mengungkapkan dan mencurahkan ide, pikirannya melewati lembar- lembar kerja yang harus dikerjakan oleh peserta baik secara individu maupun berkelompok. 
2. Berangkat Dari Pengalaman Belajar (Experiential Learning)

Experiential Learning Cycle terdiri dari 5 langkah yaitu pada gambar 1 .

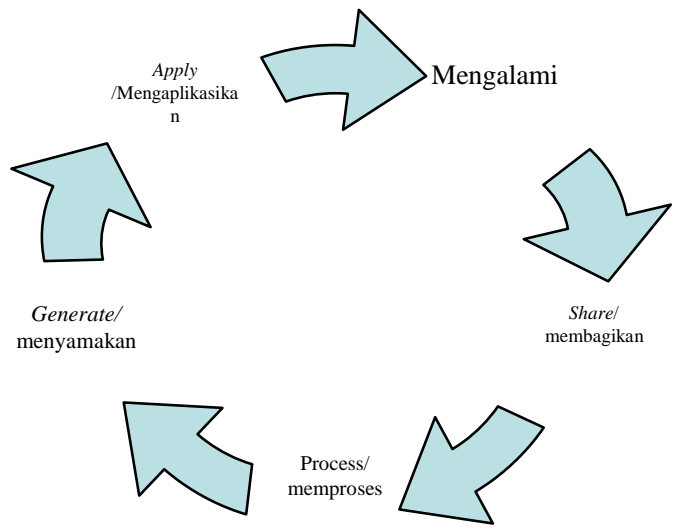

Gambar 1.Experiental Learning Cycle (Panduan Pembelajaran YEP USAID), 2018

Langkah pertama, mengalami, untuk dapat fase mengalami, peserta diberikan role play, quiz, games yang berhubungan dengan materi yang akan diberikan, peserta diharapkan dapat berpartisipasi aktif pada langkah ini. Setiap peserta yang kurang aktif, trainer akan memberikan stimulus sehingga dapat memberikan feedback dari peserta. Langkah kedua share, membagikan pengalaman, peserta diberi kesempatan untuk mengungkapkan apa yang mereka alami sesuai dengan pengalamannya masing- masing, porsi share diupayakan adil kepada semua peserta. Peserta dapat mengekspresikan pengalamannya berkaitan dengan isi modul yang sedang diberikan. Langkah ketiga process, peserta memproses apa yang mereka rasakan dalam diskusi dan menyamakan pendapat dengan sesama peserta. Langkah keempat generate, menyamakan apa yang dirasakan dengan teori atau dengan kenyataan sehari-hari sehingga peserta diberi gambaran nyata. Terakhir Apply, bagaimana peserta mengaplikasikan nya dalam kehidupan sehari- hari. Diberi penguatan pada langkah 5 ini sehingga peserta mengungkapkan penerapannya dalam kehidupan sehari- hari.

3. Berorientasi Pada Tujuan (Goals Oriented)

Semua tahap pembelajaran yang dilakukan mengarah kepada tujuan dari pembelajaran.

4. Menekankan Kerja Sama

Setiap langkah pada modul banyak melibatkan interaksi peserta secara berkelompok sehingga dibutuhkan kerja sama tim yang baik.

Semua langkah dalam pembelajaran ini merupakan proses partisipatif yang diharapkan dapat memberikan pengetahuan baru kepada peserta pelatihan dan dapat membuat peserta memahami tujuan dari modul yang disampaikan oleh trainer. Pelatihan Financial Life Skills penting untuk menunjang soft skill yang lain (Siswati, 2019), seiring dengan penelitian di Universitas Malang, bahwa metode partisipatif meningkatkan pemahaman peserta pelatihan.

\subsection{Hasil Pelatihan}

Pelaksanaan kegiatan berlangsung selama dua hari, respons para peserta ketika mengikuti Financial Life Skills Training sangat antusias. Salah satu yang membuat menarik karena metode pelatihan yang dipakai sangat bervariasi. Proses pembelajaran aktif yang digunakan adalah Experiential Learning, melalui presentasi, diskusi, brainstorming, games dan role play (Zulbetti \& Ratna, 2018).

Penekanan dan penguatan pada akhir pelatihan memberikan gambaran bahwa peserta berkeinginan melakukan pencatatan keuangan dan berharap dapat dipraktikan dalam kehidupan sehari - hari. Pada tabel 5 menggambarkan hasil pretest dan posttest peserta selama mengikuti kegiatan ini.

Tabel 5. Hasil Penilaian

\begin{tabular}{|c|c|c|c|}
\hline $\begin{array}{c}\text { No } \\
\text { Peserta }\end{array}$ & $\begin{array}{c}\text { Nilai Pre- } \\
\text { Test }\end{array}$ & $\begin{array}{c}\text { Nilai } \\
\text { Post-Test }\end{array}$ & $\begin{array}{c}\text { Perubahan } \\
\text { nilai }\end{array}$ \\
\hline 1 & 4 & 7 & 3 \\
\hline 2 & 4 & 8 & 4 \\
\hline 3 & 6 & 6 & 0 \\
\hline 4 & 6 & 7 & 1 \\
\hline 5 & 4 & 6 & 2 \\
\hline 6 & 5 & 8 & 3 \\
\hline 7 & 5 & 9 & 3 \\
\hline 8 & 3 & 6 & 2 \\
\hline 9 & 6 & 8 & 2 \\
\hline 10 & 6 & 8 & 1 \\
\hline 11 & 6 & 8 & 0 \\
\hline 12 & 7 & 8 & 0 \\
\hline 13 & 8 & 8 & 1 \\
\hline 14 & 7 & 7 & 1 \\
\hline 15 & 7 & 8 & 0 \\
\hline 16 & 7 & 8 & \\
\hline 17 & 7 & 7 & \\
\hline & Sumber : diolah penulis $(2020)$ & \\
\hline & & & 20 \\
\hline
\end{tabular}

Berdasarkan hasil penilaian sebelum pelatihan dan setelah pelatihan, tabel 6 menunjukkan perolehan nilai rata- rata 5,76 untuk nilai pre-test dan 7,47 pada nilai post-test.

Tabel 6. Nilai Rata- Rata Descriptive Statistics

\begin{tabular}{|l|r|r|r|r|r|}
\hline \multicolumn{7}{|c|}{ Descriptive Statistics } \\
\hline & N & \multicolumn{1}{|c|}{ Min } & \multicolumn{1}{c|}{ Max } & \multicolumn{1}{c|}{ Mean } & Std. Deviation \\
\hline Pre & 17 & 3 & 8 & 5.76 & 1.393 \\
\hline Post & 17 & 6 & 9 & 7.47 & .874 \\
\hline Valid N & 17 & & & & \\
\hline
\end{tabular}

Sumber : diolah penulis (2020)

Dari nilai rata-rata terdapat kenaikan sebesar 1,71 artinya semua orang di rata-ratakan mengalami kenaikan selama pelatihan ini berlangsung. Metode partisipatif 
yang diterapkan mampu memberikan pemahaman pada peserta sehingga peserta lebih mengerti dan dapat menjawab pertanyaan secara benar. Perubahan nilai berkisar antara $0-4$ poin dari setiap pesertanya, hal ini menunjukkan peserta menjawab dengan benar dan tidak ada yang menjawab dengan salah sehingga mengalami penurunan nilai pada post-test.

Untuk mengetahui apakah pelatihan ini berhasil atau tidak, selain dengan mengukur tingkat pemahaman peserta, juga diukur melalui tingkat kepuasan peserta terhadap pelatihan ini menggunakan form 6B (mengukur kepuasan peserta). Apa yang menjadi pelatihan ini begitu bermakna bagi peserta? Sebagian dari jawabannya terletak pada konten pendidikan yang relevan dan bagaimana menerapkannya(Dwi, Sulistyorini Amidjono; John Brock; Ebi, 2018). Penilaian merupakan hasil dari kepuasan peserta terhadap 14 modul yang diberikan. Pada tabel 6 terlihat nilai yang diberikan oleh peserta pelatihan

Tabel 7. Hasil Penilaian Kepuasan Peserta

\begin{tabular}{|c|c|c|c|c|c|c|c|c|}
\hline \multirow{2}{*}{$\begin{array}{l}\text { No. } \\
\text { Modul }\end{array}$} & \multicolumn{5}{|c|}{ Grade } & \multirow{2}{*}{$\begin{array}{l}\text { Nilai } \\
\text { Max }\end{array}$} & \multirow{2}{*}{$\begin{array}{l}\text { Nilai } \\
\text { Peserta }\end{array}$} & \multirow{2}{*}{$\%$} \\
\hline & 1 & 2 & 3 & 4 & 5 & & & \\
\hline 1 & & & & 7 & 10 & 85 & 78 & $91,7 \%$ \\
\hline 2 & & & 2 & 7 & 8 & 85 & 74 & $87 \%$ \\
\hline 3 & & 1 & 3 & 5 & 8 & 85 & 71 & $83,5 \%$ \\
\hline 4 & & & 2 & 7 & 8 & 85 & 74 & $87 \%$ \\
\hline 5 & & & & 5 & 12 & 85 & 83 & $97,4 \%$ \\
\hline 6 & & & & 1 & 16 & 85 & 84 & $98,8 \%$ \\
\hline 7 & & & & 2 & 15 & 85 & 83 & $97,4 \%$ \\
\hline 8 & & & & 2 & 15 & 85 & 83 & $97,4 \%$ \\
\hline 9 & & & 2 & 5 & 8 & 85 & 66 & $77,6 \%$ \\
\hline 10 & & & 2 & 3 & 12 & 85 & 78 & $91,7 \%$ \\
\hline 11 & & & 4 & 2 & 11 & 85 & 75 & $88,2 \%$ \\
\hline 12 & & & 2 & 2 & 13 & 85 & 79 & $92,9 \%$ \\
\hline 13 & & & & 2 & 15 & 85 & 83 & $97,4 \%$ \\
\hline 14 & & & & 2 & 15 & 85 & 83 & $97,4 \%$ \\
\hline & & & & & & & & $92,5 \%$ \\
\hline
\end{tabular}

Sumber : Form 6B,diolah penulis (2020)

Dari form yang telah diolah terdapat nilai kepuasan terhadap pelatihan sebesar $92,5 \%$. Nilai ini menunjukkan peserta merasa metode partisipatif yang digunakan dalam pelatihan ini membuat mereka puas dan secara keseluruhan pelatihan dapat diterima manfaatnya oleh peserta. Seseorang yang memiliki literasi keuangan yang baik akan memiliki kualitas keputusan keuangan yang baik (Septina dkk, 2021), didukung dengan metode partisipatif akan memberikan pemahaman yang mendalam.

\section{KESIMPULAN}

Dari hasil penelitian metode partisipatif yang digunakan pada pelatihan Financial Life Skills, dapat diambil kesimpulan bahwa gambaran umum soft skills peserta dari Tridaya Group tergolong baik, yang dapat diartikan peserta mempunyai keterampilan hidup yang baik untuk dapat melakukan pekerjaan peserta di dalam kehidupan sehari - hari. Pengetahuan tentang literasi keuangan sudah ada namun masih ada yang belum mampu mengelola uangnya dengan baik ditunjukkan peserta belum bisa berinvestasi ataupun menyisihkan gajinya untuk ditabung dan dijadikan dana darurat. Berdasarkan hasil penelitian (nilai dari pre-test dan posttest) dapat pula dilihat terjadi perbedaan yang nyata pada pelatihan Finansial Life Skills. Hal ini menunjukkan metode partisipatif yang digunakan mampu meningkatkan pemahaman materi yang diberikan sehingga meningkatkan nilai peserta. Pelatihan Financial Life Skills sangat diperlukan guna meningkatkan skill atau pengetahuan di bidang literasi (sadar) keuangan sehingga mampu mengelola keuangan dari gaji yang mereka dapat. Pelatihan Financial Life Skills ini yang dapat mendorong penerapan kesempatan belajar bagi manusia demi kesejahteraan dalam kondisi kehidupan abad 21 .

\section{SARAN}

Penggunaan metode partisipatif membuktikan meningkatkan pemahaman peserta pada materi yang diberikan, untuk mendukung berjalannya metode partisipatif secara utuh perlu pengetahuan yang banyak dari trainer tentang bagaimana cara membangun komunikasi dan kepercayaan dengan peserta sehingga peserta sangat mudah berpartisipasi pada setiap modul yang diberikan. Berbagai macam games, quiz, role play harus betul- betul dipersiapkan oleh trainer sehingga pelatihan berjalan lancar dan peserta tidak bosan dengan aneka games yang beragam.

\section{DAFTAR PUSTAKA}

Dwi, Sulistyorini Amidjono; John Brock; Ebi, J. (2018). Financial Literacy In Indonesia. In Internationa Handbook Of Financial Literacy.

Elian, A. F., \& Ilyas, I. (2020). Pelaksanaan Metode Pembelajaran Partisipatif Pada Kursus Mahacoustic Music Management Di Kota Semarang. Aksara: Jurnal Ilmu Pendidikan Nonformal, 6(2), 111. Https://Doi.Org/10.37905/Aksara.6.2.111-120.2020

Komalasari, A. (2013). English As A Foreign Languange Learners Through A Reflection Project. Icel Procediing, $I$.

Lopus, J. S., Amidjono, D. S., \& Grimes, P. W. (2019). Improving Financial Literacy Of The Poor And Vulnerable In Indonesia: An Empirical Analysis. International Review of Economics Education, 32(February), 100168. Https://Doi.Org/10.1016/J.Iree.2019.100168

Ludlum, M., Hongell, L., Tigerstedt, C., Steelman, B., \& Reese, C. (2019). Financial Life Skills Of Finnish College Students: A Pilot Study On Credit Cards And Budgets. Journal Of Higher Education Theory And Practice, 19(4), 60-72. Https://Doi.Org/10.33423/Jhetp.V19i4.2202 
Septina, N., Djajadikerta, H., Setiawan, A., Danil, L., Universitas, D., \& Parahyangan, K. (2021). Pelatihan Daring Financial Life Skills: Alternatif Literasi Keuangan Di Masa Pandemi. 1(1), 50-56.

Shaanika, A.. (2018). Students' Attitudes Toward Personal Financial Planning: A Case Study Of Master Of Business Administration Students At The University Of Namibia. (Issue August).

Sharma, S., Arora, K., Sinha, R. K., Akhtar, F., \& Mehra, S. (2021). Evaluation Of A Training Program For Life Skills Education And Financial Literacy To Community Health Workers In India: A QuasiExperimental Study. 4, 1-10.

Siswati, A. (2019). Eksperiental Learning Pelatihan Financial Life Skills Pada Mahasiswa Universitas Merdeka Malang. Jurnal Bisnis Dan Managemen, 6(2), 81-87.

Taufik, R., Hustim, R., \& Nurlina, N. (2014). Penerapan Pembelajaran Partisipatif Metode True-False Dalam Pembelajaran Fisika Pada Siswa Kelas Viib Smp Negeri 17 Bulukumba. Jurnal Pendidikan Fisika Unismuh, 2(3), 120709.

Wahyu Rahmat Maulana. (2016). Pengaruh Tingkat Kesejahteraan Guru Dan Komitmen Organisasi Terhadap Kinerja Guru (Penelitian Di Sd Amaliah Ypspiai Ciawi - Bogor)Wahyu Rahmat Maulana Program Pascasarjana Institut Agama Islam Negeri Surakarta.

Zulbetti, R., Perwito, P., \& Puspita, V. A. (2019). Upaya Peningkatan Literasi Keuangan Pengurus BUMDES Melalui Pelatihan Keuangan di Kecamatan Cimaung Kabupaten Bandung. Ekonomikawan: Jurnal Ilmu Ekonomi dan Studi Pembangunan, 19(2).

Zulbetti, R., \& Ratna, P. ; Y. (2018). Pelatihan Financial Life Skills (Fls)Untuk Membangun. Sembadha 2018, $1,144-150$.

\section{UCAPAN TERIMAKASIH}

Terima kasih diucapkan kepada para peserta Financial Life Skills dari Tridaya Group, pelatih Financial Life Skills YEP USAID, rekan kerja UNIGA dan Politeknik Piksi Ganesha Bandung. 